\title{
Pequi (Caryocar brasiliense Camb.) by-product for lambs: Performance, feed intake, and nutrient digestibility
}

\author{
Subproducto de pequi (Caryocar brasiliense Camb.) para corderos: Desempeño, consumo y digestibilidad \\ de nutrientes
}

\begin{abstract}
Subproduto de pequi (Caryocar brasiliense Camb.) em cordeiros: Desempenho, consumo e digestibilidade dos nutrientes
\end{abstract}

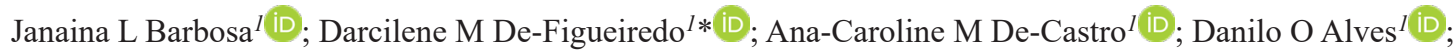
Marcela A Magalhães $^{1}$ (D); Mário H F Mourthé (D); Marianne Schorer $^{1}$ (D); Gabriel M Dallago 1 (D).
\end{abstract}

${ }^{1}$ Universidade Federal dos Vales do Jequitinhonha e Mucuri-UFVJM-Campus JK, Diamantina-MG, Brazil.

${ }^{2}$ Instituto de Ciências Agrárias, Universidade Federal de Minas Gerais-UFMG, Montes Claros-MG, Brazil.

To cite this article:

Barbosa JL, De-Figueiredo DM, De-Castro ACM, Alves DO, Magalhães MA, Mourthé MHF, Schorer M, Dallago GM. Pequi (Caryocar brasilienseCamb.)byproductforlambs:Performance,feedintake, andnutrientdigestibility.RevColombCiencPecu.2021;34(2):105-116. DOI: $\underline{\text { https://doi.org/10.17533/udea.rccp.v34n4a04 }}$

\section{Abstract}

Background: The use of pequi by-product as animal feed is an appealing alternative to reduce overall production costs. However, little is known regarding its effects on animal performance as well as the ideal inclusion level in the diet. Objective: To evaluate performance, intake, and digestibility of confined lambs receiving diets containing different levels of pequi byproduct as a partial substitute for corn silage. Methods: The experiment was conducted in Curvelo, Brazil, using twenty-five crossbred Santa Inês male lambs $(17.83 \pm 1.73 \mathrm{~kg})$ aged six months for 92 days. Increasing levels of pequi by-product $(0,6,12$, 18 , and $24 \%$ ) replacing corn silage were evaluated in a completely randomized design. Analysis of variance and regression were performed, with 5\% significance level. Results: Inclusion of pequi by-product did not influence $(p>0.05)$ average daily gain, total weight gain, or feed conversion ratio. No effect $(\mathrm{p}>0.05)$ was also observed on intake of dry matter, organic matter, ether extract, crude protein, neutral detergent fiber, total carbohydrates, and total digestible nutrients. However, a linear decrease was observed $(\mathrm{p}<0.05)$ in the apparent digestibility of dry matter, organic matter, ether extract, crude protein, neutral detergent fiber, total carbohydrates, and total digestible nutrients with increasing inclusion of pequi by-product. Conclusion: Pequi by-product is a potential substitute for corn silage in lamb diets because it does not influence animal performance and feed intake. However, digestibility decreases with increasing dietary inclusion levels of pequi by-product.

Keywords: Alternative feedstuff; animal performance; feed intake; fruit by-product; fruit residue; lamb; digestibility; pequi; sheep; weight gain.

Received: June 1, 2018; accepted: October 6, 2020

*Corresponding author. Rodovia MGT 367 - Km 583, n 5000, Diamantina, Minas Gerais, Brasil. Postal Code: 39100-000. Tel.: +55 38 3532-1200 extension 8510. Cel.: +55 38 98845-5770. Email: darcilenefigueiredo@ufvjm.edu.br 


\section{Resumen}

Antecedentes: la inclusion de subproductos de pequi en alimentación animal es una estrategia atractiva para reducir los costos de producción. Sin embargo, todavía se sabe poco sobre el efecto de este subproducto en el rendimiento de los animales, así como su nivel ideal de inclusión en la dieta. Objetivo: evaluar el rendimiento, consumo y digestibilidad en corderos confinados recibiendo dietas con subproducto de pequi en reemplazo parcial del ensilado de maíz. Métodos: el experimento se realizó en Curvelo, Brasil, utilizando 25 corderos machos cruzados de raza Santa Inês $(17,83 \pm 1,73 \mathrm{~kg})$ y $6 \mathrm{meses}$ de edad, durante 92 días. Se evaluaron niveles crecientes del subproducto de pequi $(0,6,12,18$ y 24\%) para sustituir el ensilado de maíz siguiendo un diseño completamente aleatorio. Los análisis de varianza y regresión se llevaron a cabo usando un nivel de significancia del 5\%. Resultados: la inclusión del subproducto de pequi no influyó ( $\mathrm{p}>0,05)$ en la ganancia de peso diaria, ganancia de peso total, ni conversión alimenticia. No se observó efecto $(\mathrm{p}>0,05)$ en la ingesta de materia seca, materia orgánica, extracto etéreo, proteína bruta, fibra detergente neutra, carbohidratos totales y nutrientes digestibles totales. Sin embargo, se observó una reducción lineal $(\mathrm{p}<0,05)$ en la digestibilidad aparente de materia seca, materia orgánica, extracto etéreo, proteína bruta, fibra detergente neutra, carbohidratos totales y nutrientes digestibles totales con el aumento del nivel de inclusión del subproducto. Conclusión: el subproducto de pequi puede utilizarse como sustituto parcial del ensilado de maíz, ya que no afecta la ganancia de peso ni la ingesta de nutrientes. Sin embargo, la digestibilidad disminuye al aumentar el nivel de inclusión del subproducto en la dieta.

Palabras clave: cordero; digestibilidad; ganancia de peso; ingesta; oveja; pequi; piensos alternativos; rendimiento animal; residuos de fruta; subproducto de fruta.

\section{Resumo}

Antecedentes: o uso de subprodutos do pequi na alimentação animal é uma estratégia atraente que busca a redução dos custos de produção. Entretanto, pouco ainda se sabe sobre o efeito desse subproduto no desempenho animal assim como qual seria o nível ideal da sua inclusão na dieta. Objetivo: avaliar o desempenho, consumo e digestibilidade em cordeiros confinados recebendo dietas contendo subproduto de pequi em substituição à silagem de milho. Métodos: o experimento foi conduzido em Curvelo, Brasil, utilizando 25 cordeiros machos cruzados da raça Santa Inês $(17,83 \pm 1,73 \mathrm{~kg})$ com 6 meses de idade durante 92 dias. Níveis crescentes do subproduto de pequi $(0,6,12,18$ e 24\%) foram avaliados em substituição à silagem de milho em um delineamento inteiramente casualizado. A análise de variância e regressão foram conduzidas adotando $5 \%$ como nível de significância. Resultados: a inclusão do subproduto de pequi não influenciou ( $\mathrm{p}>0,05)$ o ganho de peso médio diário, o ganho de peso total e a conversão alimentar. Também não foi observado efeito $(\mathrm{p}>0,05)$ no consumo de matéria seca, matéria orgânica, extrato etéreo, proteína bruta, fibra em detergente neutro, carboidratos totais e nutrientes digestíveis totais. Entretanto, foi observada redução linear $(\mathrm{p}<0,05)$ na digestibilidade aparente da matéria seca, matéria orgânica, extrato etéreo, proteína bruta, fibra em detergente neutro, carboidratos totais e nutrientes digestíveis totais com o aumento da inclusão do subproduto. Conclusão: o subproduto de pequi pode ser utilizado como substituto parcial à silagem de milho uma vez que não influenciou o desempenho animal ou o consumo de nutrientes. No entanto, a digestibilidade diminuiu com o aumento do nível de inclusão do subproduto na dieta.

Palavras-chave: alimentos alternativos; consumo; subproduto de fruta; cordeiro; desempenho animal; digestibilidade; ganho de peso; ovino; pequi; resíduo de fruta. 


\section{Introduction}

The use of alternative feeds from plant by-products in animal diets can reduce the environmental impact of the livestock industry (Lousada Junior et al., 2005; Salami et al., 2019) and feeding cost (Lousada Junior et al., 2005), as well as the competition with human food (Lousada Junior et al., 2005; Salami et al., 2019). Previous studies indicated the feasibility of using different fruit by-products as feed for small ruminants (Almeida et al., 2019; Almeida et al., 2015). However, many by-products are wasted due to lack of knowledge about its potential use. Pequi by-product is an example of a plant by-product with potential to be used in ruminant feeding.

Pequi is the fruit of the "pequizeiro" (Caryocar brasiliense Camb.), which is a native tree present in tropical areas of Latin America. The main economic interest of pequi lies in the extraction of its core (pyrene: internal mesocarp, thorny endocarp, and edible almond), which represents between 17.9 to $22.5 \%$ of the fruit (Alves et al., 2014; Soares Júnior et al., 2010). In contrast, the shell (exocarp and external mesocarp), which represents between 76.0 to $82.1 \%$ of the fruit (Alves et al., 2014; Soares Júnior et al., 2010), has a latent interest and is the main by-product of pequi. In 2019, 3.28 million tons of pequi were commercialized in the four main producing states in Brazil (CEASA-GO, 2020). The extraction of the fruit's core would result in 2.49 to 2.69 million tons of byproducts that could be incorporated in ruminant diets, potentially reducing overall production costs and increasing the environmental sustainability of the activity.

The use of pequi by-product in ruminants has received little attention in the literature. While evaluating the ruminal degradation kinetics of pequi shell in goats, Geraseev et al. (2011) reported a high potential degradability of its dry matter (DM; 93.95\%), crude protein $(\mathrm{CP}$; $88.16 \%$ ), and neutral detergent fiber (NDF; $82.39 \%$ ). They also reported a linear increase in potential degradability of DM and NDF with increasing levels of the by-product as a partial substitute for elephant grass. Nevertheless, further studies are required to evaluate its suitability for different animal species in combination with different roughage sources.

Therefore, the objective of this study was to evaluate performance, intake, and digestibility of diets with increasing levels of pequi byproduct as a partial substitute for corn silage in lambs.

\section{Materials and Methods}

\section{Ethical considerations}

The Ethics Committee on the Use of Animals from Universidade Federal dos Vales do Jequitinhonha e Mucuri (UFVJM) approved the experimental procedures used in this study (26/ June/2013, Protocol no 008/2013).

\section{Experiments}

The experiment was conducted in the Ruminants Laboratory at the Experimental Farm of Moura (EFM) of UFVJM, located in Curvelo - MG, Brazil. Bromatological analyses were carried out in the Food Analysis Laboratory of UFVJM - JK Campus, Diamantina - MG.

\section{Animals and study design}

The pequi by-product was collected in a fruit-processing cooperative located in the city of Japonvar - MG. The by-product consisted of pequi shells (exocarp and external mesocarp), resulting from extraction of the fruit core (pyrene: internal mesocarp, thorny endocarp, and edible almond). The byproduct was transported to the EFM, placed on black plastic canvas forming 5 -cm thick layers, exposed to the sun for drying and turned three times a day. The by-product was ground on 5-mm sieve when it reached a dry and crumbly aspect.

The experiment length was 92 days -between August 13 and November 11, 2012. After a 10-days adaptation, followed by three 28-day periods, the last one being 26 days for data collection. Twenty-five non-castrated male 
crossbred Santa Inês lambs, averaging $17.83 \pm$ $1.73 \mathrm{~kg}$ body weight (BW) and six months of age were used. Lambs were kept in $1.5 \times 1.0$ $\mathrm{m}$ individual metabolic cages equipped with individual feeder and drinker. The cages were cleaned daily. All animals were orally dewormed against endoparasites at the beginning of the experiment.

The animals were fed a total-mixed ration with a 50:50 forage to concentrate ratio (dry matter basis). The concentrate was formulated with ground corn, soybean meal, urea, and mineral mix (Table 1). Diets were balanced for $200 \mathrm{~g}$ daily weight gain, according to the requirements for 20 $\mathrm{kg} \mathrm{BW}$ animals, as recommended by the NRC (2007). The diet contained approximately $16 \%$ $\mathrm{CP}$ and $70 \%$ total digestible nutrients (TDN).

Table 1. Ingredients composition of the experimental diets offered to confined lambs.

\begin{tabular}{lccccc}
\hline \multirow{2}{*}{ Item* } & \multicolumn{5}{c}{ Pequi by-product levels (\%) } \\
\cline { 2 - 6 } & $\mathbf{0}$ & $\mathbf{6}$ & $\mathbf{1 2}$ & $\mathbf{1 8}$ & $\mathbf{2 4}$ \\
\hline Ground corn & 31.0 & 31.0 & 31.0 & 31.0 & 31.0 \\
Soybean meal & 16.0 & 16.0 & 16.0 & 16.0 & 16.0 \\
Urea & 1.35 & 1.35 & 1.35 & 1.35 & 1.35 \\
Ammonium sulfate & 0.15 & 0.15 & 0.15 & 0.15 & 0.15 \\
Mineral mixture & 1.50 & 1.50 & 1.50 & 1.50 & 1.50 \\
Corn silage & 50.0 & 44.0 & 38.0 & 32.0 & 26.0 \\
Pequi by-product & 0.00 & 6.00 & 12.0 & 18.0 & 24.0 \\
\hline
\end{tabular}

*Values are expressed on dry matter basis (g/100 g of dry matter).

Five levels of inclusion of pequi by-product were evaluated as follow based on percentage of dry matter content: Treatment $1=$ corn silage $(50 \%)$ and concentrate $(50 \%)$ (control); Treatment $2=$ corn silage $(44 \%)$, pequi byproduct $(6 \%)$, and concentrate $(50 \%)$; Treatment $3=$ corn silage $(38 \%)$, pequi by-product $(12 \%)$, and concentrate $(50 \%)$; Treatment $4=$ corn silage $(32 \%)$, pequi by-product (18\%), and concentrate $(50 \%)$; Treatment $5=$ corn silage $(26 \%)$, pequi by-product $(24 \%)$, and concentrate $(50 \%)$.

The mixture of roughage and concentrate was done right before the animals were fed. It was provided ad libitum two times a day at $08 \mathrm{~h} 00$ am and $04 \mathrm{~h} 00 \mathrm{pm}$, allowing approximately $10 \%$ leftovers. The animals had ad libitum access to water and mineral mixture.

The chemical composition of pequi byproduct, corn silage, and experimental diets obtained from samples collected over the entire experimental period are shown in Table 2.

Forage and concentrate offered were daily recorded throughout the experiment to measure individual consumption. Diet and leftovers were daily sampled, placed in plastic bags, and stored in the freezer for future analyses. Animals were weighed at the beginning and the end of each period for assessing total body weight and average daily gain. Nutrient intake was calculated as percentage of body weight (\% $\mathrm{BW})$, relation to metabolic weight $\left(\mathrm{g} / \mathrm{BW}^{0.75}\right)$, and in kilograms per day ( $\mathrm{kg} /$ day). Average daily gain (ADG) was calculated as the difference between initial and final BW over the number of days evaluated. Feed conversion ratio (FCR) was obtained from the relationship between average dry matter intake and average BW gain.

Digestibility trials were carried out from the 11 th to the 18th day of the second experimental period (eight consecutive days) to estimate apparent digestibility of nutrients. The total amount of feces produced was collected using nappa leather bags ( $83 \%$ polyester and $17 \%$ cotton) attached to the animal during the 1st and 7 th days of the trial. Before the morning feeding, the feces were weighed, sampled (about 10\% of the total), and kept frozen at $-20{ }^{\circ} \mathrm{C}$ for later analyses.

\section{Laboratory analysis and measurements}

Corn silage, pequi by-product, concentrate and dried leftovers samples were ground in a Wiley mill (Thomas Model 4 Wiley® Mill; Thomas Scientific, Swedeboro, NJ, USA) to pass through a 1-mm stainless steel curved round-hole sieve. Samples were analyzed for dry matter (DM), organic matter (OM), crude protein (CP), ether extract (EE), and ash content according to the AOAC (1997). The NDF values were obtained according to Mertens (2002), 
without sodium sulphite, but using heat-stable alpha-amylase (Novo A/S, Hellerup, Denmark). We used the Ankom ${ }^{\circledR}$ NDF determination system with non-woven fabric bags $(5.0 \times 5.0$ $\mathrm{cm}, 100$ micrometres porosity, TNT $\left.100 \mathrm{~g} / \mathrm{m}^{2}\right)$. Contents of ADF, ADIN, INND, and lignin
(72\% sulfuric acid) were obtained by sequential method (Robertson and Van Soest, 1981), and presented as suggested by Licitra et al. (1996). Analysis of condensed tannins was conducted only for the pequi by-product using the hot water method according to Trugilho et al. (2003).

Table 2. Chemical composition of pequi by-product, corn silage, and experimental diets.

\begin{tabular}{lccccccc}
\hline \multirow{2}{*}{ Item } & \multirow{2}{*}{ Pequi by-product } & \multirow{2}{*}{ Corn silage } & \multicolumn{5}{c}{ Pequi by-product levels (\%) } \\
\cline { 4 - 8 } & & & $\mathbf{0}$ & $\mathbf{6}$ & $\mathbf{1 2}$ & $\mathbf{1 8}$ & $\mathbf{2 4}$ \\
\hline DM* $^{*}$ & 89.46 & 24.65 & 53.62 & 57.52 & 61.86 & 65.74 & 69.63 \\
OM* $^{*}$ & 94.32 & 94.74 & 94.42 & 94.37 & 94.31 & 94.28 & 94.26 \\
Ash* & 5.68 & 5.26 & 4.07 & 4.12 & 4.18 & 4.21 & 4.23 \\
EE* & 2.93 & 2.75 & 2.91 & 2.92 & 2.93 & 2.94 & 2.95 \\
CP* & 4.54 & 8.79 & 16.99 & 16.92 & 16.90 & 16.63 & 16.36 \\
NDFap* & 28.62 & 61.23 & 40.90 & 38.93 & 37.11 & 35.21 & 33.32 \\
ADFap* & 19.14 & 30.63 & 15.17 & 14.70 & 14.25 & 13.77 & 13.29 \\
AIAD* & 0.29 & 0.42 & 0.27 & 0.26 & 0.25 & 0.24 & 0.23 \\
AIND* & 0.62 & 1.47 & 0.45 & 0.43 & 0.41 & 0.39 & 0.36 \\
ADIN** & 29.11 & 9.95 & 4.98 & 6.12 & 7.26 & 8.40 & 9.54 \\
INND** & 51.38 & 40.01 & 20.01 & 20.69 & 21.37 & 22.05 & 22.77 \\
Lignin* & 5.95 & 3.46 & 3.66 & 3.82 & 3.99 & 4.14 & 4.29 \\
NFC* & 62.12 & 23.19 & 38.19 & 40.11 & 42.39 & 44.51 & 46.64 \\
TCHO* & 86.85 & 83.20 & 76.02 & 76.03 & 75.97 & 76.21 & 76.44 \\
Tannin* & 9.80 & --- & 0.00 & 0.58 & 1.17 & 1.76 & 2.35 \\
\hline
\end{tabular}

*Values are expressed on dry matter basis ( $\mathrm{g} / 100 \mathrm{~g}$ of dry matter). **Values are expressed on total nitrogen basis ( $\mathrm{g} / 100 \mathrm{~g}$ of total nitrogen). Dry matter (DM), organic matter (OM), ether extract (EE), crude protein (CP), neutral detergent fiber corrected for ash and protein (NDFap), acid detergent fiber corrected for ash and protein (ADFap), ashes insoluble in acid detergent (AIAD), ash insoluble in neutral detergent (AIND), Acid detergent insoluble nitrogen (ADIN), insoluble nitrogen in neutral detergent (INND), non-fibrous carbohydrate (NFC), total carbohydrates (TCHO).

Fecal samples were analyzed for DM, OM, CP, EE, and ash, according to AOAC (1997), and NDF according to Mertens (2002).

Non-fiber carbohydrates (NFC) in leftovers and feces were estimated with the Van Soest et al. (1991)equation, using the formula: $\mathrm{NFC}=100-(\mathrm{CP}+\mathrm{EE}+$ Ash + NDFap $)$, where: $\mathrm{NFC}=$ estimated content of non-fibrous carbohydrates $(\%)$; $\mathrm{CP}=$ crude protein content $(\%) ; \mathrm{EE}=$ ether extract content $(\%) ;$ Ash $=$ ash content; and NDFap $=$ neutral detergent fiber corrected for ash and protein (\%).
Non-fiber carbohydrates (NFC) of concentrate feeds were estimated according to Hall and Akinyode (2000), using the formula: $\mathrm{NFC}=100-[($ CPtotal $\%$ - CPurea $\%+$ urea $\%)+$ $\mathrm{NDFap} \%+\mathrm{EE} \%+\mathrm{Ash} \%]$.

Total digestible nutrients (TDN) were calculated using the NRC (2001) equation: $\mathrm{TDN}=\mathrm{CPd}+2.25 \times \mathrm{EEd}+\mathrm{NDFapD}+$ NFC; where TDN = total digestible nutrients; $\mathrm{CPd}=$ digestible crude protein; $\mathrm{EEd}=$ digestible ether extract; NDFadp = neutral detergent fiber corrected for ash and digestible protein, and $\mathrm{NFC}=$ non-fibrous carbohydrates. 
Total carbohydrates (TCHO) were calculated as proposed by Sniffen et al. (1992): TC = 100 $(\mathrm{CP} \%+\mathrm{EE} \%+\mathrm{Ash} \%)$.

Similar to Valero et al. (2016), the apparent digestibility (AD) values of nutritional components of the diet were obtained using the following equation:

$$
\mathrm{AD}(\%)=\frac{(\mathrm{DM} \text { intake } \times \text { nutrient } \%)-(\mathrm{DM} \text { excreted } \times \text { nutrient } \%)}{\mathrm{DM} \text { intake } \times \text { nutrient } \%} \times 100
$$

Agro-industrial by-products used in animal diets are usually obtained after intensive processing. It often implies an intense reduction in particle size, which is associated with the physical effectiveness of fiber. Therefore, we measured the particle size on a 500-g sample of the pequi by-product using granulometric sieves of $1.00,1.18,1.40,2.36,2.80,3.35,4.00$, and $4.75 \mathrm{~mm}$. The sieves were sorted in descending order and stirred until complete passage of particles. Subsequently, portions retained on each sieve were weighed to determine the percentage of each fraction of particle sizes of the pequi by-product.

\section{Statistical analysis}

The experiment was conducted in a completely randomized design with five treatments and five replicates. The results were submitted to analyses of variance, with initial $\mathrm{BW}$ as a covariate, and regression considering $5 \%$ probability or lower for type I error using the SAS software, version 9.0 (SAS, 2002).

\section{Results}

Pequi by-product showed higher amounts of lignin than corn silage. Based on dry matter, pequi by-product had 5.95\% while corn silage had $3.46 \%$ lignin (Table 2). Consequently, the higher the inclusion of pequi by-product, the more lignin was included in the diet. However, the difference between the highest and lowest lignin content in the diet was only about $0.63 \%$ (Table 2 ).
There was no effect ( $p>0.05)$ of pequi byproduct as replacement of corn silage on intake of DM, OM, CP, EE, NDFap, NFC, TCHO, and TDN, regardless of how they were expressed: $\% \mathrm{BW}, \mathrm{g} / \mathrm{BW}^{0.75}$, or kg/day (Table 3 ). In addition, there was no change on NDF and NFC intake (Table 3), despite the reduction of NDF and increase of NFC in the diets with the inclusion of pequi by-product (Table 2).

More than $60 \%$ of the pequi by-product measured $1.18 \mathrm{~mm}$ or above, as presented in Table 4.

There was a negative $(\mathrm{p}<0.01)$ linear effect on the apparent digestibility of nutritional constituents with the inclusion of pequi byproduct (Table 5). The absolute digestibility value of DM, OM, EE, CP, NDFap, NFC, and TDN, decreased linearly $(11.67,12.35,23.41$, $17.92,12.64,9.24$, and $6.77 \%$, respectively) between zero and $24 \%$ inclusion of pequi by-product (Table 5). Decreased $(p<0.01)$ digestibility of TDN was expected since it was calculated based on digestible CP, EE, NDFap, and $\mathrm{NFC}$, where a reduction in digestibility $(p<0.01)$ was also observed (Table 5).

No significant effect $(p>0.05)$ was observed of treatments on average daily gain and days to reach $30 \mathrm{~kg}$ of $\mathrm{BW}$ (Table 6). The animals gained $224 \mathrm{~g} /$ day on average. No effect $(\mathrm{p}>0.05)$ on feed conversion rate was expected since the feed conversion ratio was calculated based on total intake and total weight gain, which in turn were not statistically significant $(p>0.05)$. The average number of days to reach $30 \mathrm{~kg}$ was 65.38 and no effect $(\mathrm{p}>0.05)$ of pequi by-product was observed.

\section{Discussion}

We evaluated the partial replacement of corn silage by increasing levels of pequi byproduct in diets fed to lambs and its effect on animal performance, feed intake, and nutrient digestibility to assess the suitability of this byproduct as a potential feed source for ruminants. 
Table 3. Nutritional intake of lambs fed diets with increasing levels of pequi by-product.

\begin{tabular}{|c|c|c|c|c|c|c|c|c|c|}
\hline \multirow{2}{*}{ Item* } & \multicolumn{5}{|c|}{ Pequi by-product levels (\%) } & \multirow{2}{*}{ SEM } & \multirow{2}{*}{ Regression } & \multirow{2}{*}{ p-value } & \multirow{2}{*}{ CV $(\%)$} \\
\hline & $\mathbf{0}$ & 6 & 12 & 18 & 24 & & & & \\
\hline \multicolumn{10}{|c|}{$\% B W$} \\
\hline $\mathrm{DM}$ & 4.01 & 3.95 & 4.31 & 4.15 & 3.83 & 0.10 & $\hat{y}=4.05$ & 0.40 & 16.69 \\
\hline $\mathrm{OM}$ & 3.81 & 3.75 & 4.08 & 3.92 & 3.62 & 0.09 & $\hat{\mathrm{y}}=3.83$ & 0.39 & 16.66 \\
\hline $\mathrm{EE}$ & 0.11 & 0.11 & 0.12 & 0.11 & 0.10 & 0.003 & $\hat{y}=0.11$ & 0.25 & 16.27 \\
\hline $\mathrm{CP}$ & 0.83 & 0.79 & 0.84 & 0.76 & 0.69 & 0.02 & $\hat{\mathrm{y}}=0.78$ & 0.06 & 17.34 \\
\hline NDFap & 1.56 & 1.48 & 1.55 & 1.57 & 1.38 & 0.03 & $\hat{y}=1.15$ & 0.31 & 15.87 \\
\hline NFC & 1.30 & 1.35 & 1.56 & 1.46 & 1.42 & 0.04 & $\hat{\mathrm{y}}=1.42$ & 0.36 & 18.84 \\
\hline $\mathrm{TCHO}$ & 2.86 & 2.84 & 3.11 & 3.03 & 2.81 & 0.04 & $\hat{y}=2.93$ & 0.24 & 16.56 \\
\hline TDN & 2.80 & 2.63 & 2.71 & 2.65 & 2.29 & 0.08 & $\hat{y}=2.62$ & 0.21 & 16.68 \\
\hline \multicolumn{10}{|c|}{$g / B W^{0.75}$} \\
\hline DM & 89.79 & 88.14 & 97.17 & 92.41 & 85.11 & 2.23 & $\hat{y}=90.52$ & 0.39 & 16.64 \\
\hline $\mathrm{OM}$ & 85.40 & 83.57 & 92.01 & 87.37 & 80.48 & 2.12 & $\hat{y}=85.77$ & 0.38 & 16.62 \\
\hline $\mathrm{EE}$ & 2.57 & 2.50 & 2.80 & 2.62 & 2.38 & 0.07 & $\hat{y}=2.57$ & 0.25 & 16.72 \\
\hline $\mathrm{CP}$ & 18.67 & 17.80 & 19.06 & 17.13 & 15.50 & 0.50 & $\hat{y}=17.63$ & 0.06 & 17.17 \\
\hline NDFap & 34.95 & 33.11 & 34.97 & 34.95 & 30.86 & 0.76 & $\hat{y}=33.77$ & 0.32 & 15.61 \\
\hline $\mathrm{NFC}$ & 29.20 & 30.14 & 35.16 & 32.66 & 31.74 & 0.90 & $\hat{y}=31.78$ & 0.34 & 17.95 \\
\hline TCHO & 64.15 & 63.26 & 70.14 & 67.61 & 62.60 & 0.93 & $\hat{y}=65.55$ & 0.22 & 16.49 \\
\hline TDN & 62.77 & 58.60 & 61.13 & 59.18 & 51.01 & 1.86 & $\hat{\mathrm{y}}=58.54$ & 0.22 & 16.75 \\
\hline \multicolumn{10}{|c|}{$\mathrm{kg} / \mathrm{day}$} \\
\hline DM & 1.00 & 0.97 & 1.11 & 1.02 & 0.93 & 0.03 & $\hat{y}=1.01$ & 0.39 & 17.41 \\
\hline OM & 0.96 & 0.92 & 1.05 & 0.96 & 0.88 & 0.03 & $\hat{y}=0.95$ & 0.39 & 17.38 \\
\hline $\mathrm{EE}$ & 0.03 & 0.02 & 0.03 & 0.02 & 0.02 & 0.001 & $\hat{y}=0.02$ & 0.26 & 18.91 \\
\hline $\mathrm{CP}$ & 0.21 & 0.19 & 0.21 & 0.19 & 0.17 & 0.01 & $\hat{y}=0.19$ & 0.10 & 17.70 \\
\hline NDFap & 0.39 & 0.36 & 0.40 & 0.38 & 0.34 & 0.01 & $\hat{y}=0.37$ & 0.37 & 16.09 \\
\hline $\mathrm{NFC}$ & 0.32 & 0.33 & 0.40 & 0.35 & 0.35 & 0.01 & $\hat{y}=0.35$ & 0.32 & 19.00 \\
\hline $\mathrm{TCHO}$ & 0.72 & 0.70 & 0.80 & 0.74 & 0.69 & 0.01 & $\hat{\mathrm{y}}=0.73$ & 0.22 & 17.28 \\
\hline TDN & 0.70 & 0.65 & 0.70 & 0.65 & 0.56 & 0.02 & $\hat{\mathrm{y}}=0.65$ & 0.29 & 17.84 \\
\hline
\end{tabular}

*Values are expressed on dry matter basis (g/100 g of dry matter). Dry matter (DM), organic matter (OM), ether extract (EE), crude protein (CP), neutral detergent fiber corrected for ash and protein (NDFap), non-fibrous carbohydrate (NFC), total carbohydrates (TCHO), total digestible nutrients (TDN), standard error of the mean (SEM), coefficient of variation (CV).

Table 4. Proportion of particle sizes of pequi by-product using granulometric sieves on a $500 \mathrm{~g}$ sample.

\begin{tabular}{llllllllll}
\hline \multicolumn{9}{l}{ Particle Size } \\
\hline $\mathrm{mm}$ & $<1$ & $>1$ & $>1.18$ & $>1.4$ & $>2.36$ & $>2.8$ & $>3.35$ & $>4$ & $>4.75$ \\
\hline
\end{tabular}

The DM intake (4.05\% BW) was higher than the $2.97 \%$ BW presented by NRC (2007) based on the requirements of finishing lambs weighing $20 \mathrm{~kg} \mathrm{BW}$ and $200 \mathrm{~g} /$ day expected weight gain. While evaluating the performance of goats fed increasing levels of pequi by-product as a partial substitute of elephant grass, Ribeiro Junior et al. (2009) reported no effect of the byproduct inclusion on DM intake $(\mathrm{p}>0.05)$ with an average of $58.3 \mathrm{~g} / \mathrm{BW}^{0.75}$, and $0.512 \mathrm{~kg} / \mathrm{day}$, 
which were lower than the values reported in the present study (Table 3). Additionally, Almeida et al. (2019) evaluated the effect of replacing $75 \%$ of sorghum silage offered to finishing lambs by different fruit by-products (pineapple, banana, mango, or passion fruit), and reported DM intake ranging from 3.4 to $3.7 \% \mathrm{BW}$, which is similar to our study. Voluntary intake may change depending on the quality and type of feed and the physiological status of the animal (NRC, 2007). It also may change according to feed digestibility, since its ability to be more or less digestible implies meeting physical energy requirement and satiety (NRC, 2007).

Table 5. Nutritional intake of lambs fed diets with increasing levels of pequi by-product.

\begin{tabular}{|c|c|c|c|c|c|c|c|c|c|c|}
\hline \multirow{2}{*}{ Item* } & \multicolumn{5}{|c|}{ Pequi by-product levels } & \multirow{2}{*}{ SEM } & \multirow{2}{*}{ Regression } & \multirow{2}{*}{ p-value } & \multirow{2}{*}{$\mathbf{R}^{2}$} & \multirow{2}{*}{ CV (\%) } \\
\hline & $\mathbf{0}$ & 6 & 12 & 18 & 24 & & & & & \\
\hline DMD & 72.72 & 70.81 & 66.75 & 68.31 & 64.23 & 0.74 & $\hat{y}=72.46-0.39 X$ & 0.009 & 0.41 & 4.92 \\
\hline OMD & 72.28 & 70.15 & 66.13 & 67.43 & 63.35 & 0.76 & $\hat{y}=71.99-0.37 X$ & 0.006 & 0.44 & 5.01 \\
\hline EED & 78.75 & 76.68 & 73.12 & 69.17 & 60.31 & 1.64 & $\hat{y}=77.71-0.76 X$ & $<0.001$ & 0.78 & 5.64 \\
\hline CPD & 76.41 & 72.63 & 67.41 & 68.01 & 62.67 & 0.81 & $\hat{y}=75.84-0.59 X$ & $<0.001$ & 0.68 & 4.63 \\
\hline NDFapD & 62.69 & 59.83 & 53.30 & 57.14 & 54.76 & 1.14 & $\hat{y}=61.87-0.32 X$ & 0.005 & 0.24 & 11.2 \\
\hline NFCD & 84.71 & 81.14 & 77.82 & 79.14 & 76.88 & 1.08 & $\hat{y}=83.51-0.31 X$ & 0.01 & 0.34 & 4.55 \\
\hline TDND & 74.56 & 73.16 & 70.53 & 71.08 & 69.51 & 0.79 & $\hat{y}=73.86-0.21 X$ & 0.002 & 0.43 & 2.77 \\
\hline
\end{tabular}

*Values are expressed in Kg. Dry matter digestibility (DMD), organic matter digestibility (OMD), ether extract digestibility (EED), crude protein digestibility (CPD), digestibility of neutral detergent fiber corrected for ash and protein (NDFapD), nonfibrous carbohydrate digestibility (NFCD), digestibility of total digestible nutrients (TDND), standard error of mean (SEM), coefficient of determination $\left(\mathrm{R}^{2}\right)$, coefficient of variation $(\mathrm{CV})$.

Table 6. Productive performance of lambs fed diet with increasing levels of pequi by-product replacing corn silage.

\begin{tabular}{|c|c|c|c|c|c|c|c|c|c|}
\hline \multirow{2}{*}{ Item } & \multicolumn{5}{|c|}{ Pequi by-product levels (\%) } & \multirow{2}{*}{ SEM } & \multirow{2}{*}{ Regression } & \multirow{2}{*}{ p-value } & \multirow{2}{*}{ CV $(\%)$} \\
\hline & $\mathbf{0}$ & 6 & 12 & 18 & 24 & & & & \\
\hline Initial weight* & 18.13 & 17.90 & 18.16 & 17.34 & 17.62 & 0.47 & $\hat{y}=17.83$ & 0.25 & 9.84 \\
\hline Final weight* & 32.52 & 31.52 & 33.40 & 31.65 & 31.15 & 0.47 & $\hat{y}=32.05$ & 0.85 & 7.40 \\
\hline Average daily gain** & 0.234 & 0.214 & 0.248 & 0.224 & 0.200 & 0.01 & $\hat{y}=0.224$ & 0.81 & 23.53 \\
\hline Total weight gain* & 14.38 & 13.62 & 15.23 & 14.30 & 13.53 & 0.49 & $\hat{y}=14.21$ & 0.85 & 19.55 \\
\hline Days to reach $30 \mathrm{~kg}$ & 63.20 & 66.40 & 63.20 & 64.20 & 69.80 & 2.56 & $\hat{y}=65.38$ & 0.91 & 19.01 \\
\hline Feed conversion ratio & 4.43 & 4.76 & 4.74 & 4.49 & 4.86 & 0.18 & $\hat{y}=4.43$ & 0.45 & 24.14 \\
\hline
\end{tabular}

*Values are expressed in kilograms. **Values are expressed in grams. Standard error of the mean (SEM), coefficient of variation (CV).

No significant difference in nutrient intake indicates no preference for corn silage compared to pequi by-product. The NDF intake expressed as the percentage of BW found in this study $(1.15 \%$ BW) was similar to the values proposed by Van Soest (1994): between 0.8 and 1.2\% BW. In addition, NDF intake expressed as grams of metabolic weight $\left(\mathrm{g} / \mathrm{BW}^{0.75}\right)$ and $\mathrm{kg}$ per day (kg/day) in this study (Table 3 ) were 1.41 and 1.76 times higher, respectively, than the intakes reported by Ribeiro Junior et al. (2009). Even though NFC was higher on diets with greater inclusion of pequi by-product compared to the control diet, no change on NFC intake was observed, which was similar to that observed by Almeida et al. (2019) using mango by-products. Perhaps the presence of tannins in pequi byproduct may have reduced its acceptability due to its reduced palatability caused by hydrogen bonds with saliva protein and mucous (Guimarães-Beelen et al., 2006).

Most of the particle size of the pequi byproduct was above the minimum particle size 
$(1.18 \mathrm{~mm})$ necessary to ensure the maintenance of rumination, salivation, and therefore the ruminal $\mathrm{pH}$ buffering (hydrogen potential) for growing lambs (Cardoso et al., 2006).

Reduction of CP apparent digestibility may have been the result of tannins present in pequi by-product. Feed tannin concentration is considered high or moderate if it is 6 to $12 \%$ or 2 to $4 \%$ of DM, respectively (Frutos et al., 2002). Even though the concentration of tannins in the diets was lower than the high threshold, factors such as molecular weight, monomer composition (Lascano et al., 2001), and the spatial form (Rosales, 1999) of the tannin molecule can affect food consumption and digestibility. In addition, tannins can bond with proteins forming a complex which makes them unavailable for animals (Patra and Saxena, 2010; Van Soest, 1994).

Changes in cellulolytic activity and growth of fibrolytic bacteria might be the reason for the decreased digestibility of NDFap in the present study. Condensate tannin extract of different native forages from the Brazilian northeastern semiarid region showed bacteriostatic effects on Ruminococcus flavefaciens FD1 (GuimarãesBeelen et al., 2006). Furthermore, the growth of microorganisms depends on the ruminal digestion rate of structural carbohydrates and nitrogen (Russell et al., 1992). Such situation was likely impaired due to reduced digestibility of CP (Table 5), reducing microorganism growth and consequently reduced lytic activity on NDFap.

Observed ADG was higher than expected. Diets were designed to supply enough nutrients for animals weighing $20 \mathrm{~kg}$ to gain $200 \mathrm{~g} /$ day (NRC, 2007), but $224 \mathrm{~g}$ /day ADG was observed. Ribeiro Junior et al. (2009) reported $39.3 \mathrm{~g} /$ day ADG, while Almeida et al. (2019) reported 168 g/day ADG, which were 5.7 and 1.3 times lower, respectively, compared to the present study. High dry matter intake $(4.05 \%$ BW) could be the reason for the difference between expected and observed ADG. Sheep fed diets with different concentrations of metabolizable energy increase their dry matter intake, increasing their average daily gain (Pereira et al., 2010).

A reduced productive performance was expected because the inclusion of pequi byproduct negatively affected diet digestibility. However, no effect of diet on animal performance was observed (Table 6). We hypothesized the occurrence of compensatory growth. Animals used in this study were bought from different farms and it was reasonable to believe they went through some kind of feed restriction before starting the experimental period. Especially because they were kept on grazing during the dry season, which is the season of forage shortage, leading to great DMI and weight gain during the experimental period. Compensatory gain has been observed in lambs. For instance, lambs maintained under moderate feed restriction $(30 \%$ restriction) during 60 days showed higher feed intake and $\mathrm{BW}$ gain after the restriction period than non-restricted animals (Homem Junior et al., 2007). However, the duration and severity of feed restriction used in our study is unknown, making it difficult to measure the length of the compensatory growth period.

Fruit by-products can be a source of bioactive compounds such as unsaturated fatty acids, phytochemicals, and vitamins (Salami et al., 2019). Bioactive compounds in pequi byproduct have anthelmintic properties in sheep, tested in vitro and in vivo (Nogueira et al., 2012). It also has effect against gastrointestinal nematodes of cattle, tested in vitro (Fonseca et al., 2014). Extract from pequi by-product has antimicrobial properties, potentially making it an alternative to ionophores for reducing enteric methane production (Oliveira et al., 2014; Patra and Saxena, 2010). Such bioactive compounds were not evaluated in the present study; it is an area of active research.

As a conclusion, pequi by-product can substitute for corn silage up to $24 \%$ of the total $\mathrm{DM}$ of the diet since it does not affect animal performance or intake, despite reducing nutrient digestibility. The use of this by-product could potentially reduce the feeding cost of lambs. 
Further research is needed to evaluate the potential benefits of the bioactive compounds present in pequi by-product.

\section{Declarations}

\section{Funding}

This study was funded by the Coordenação de Aperfeiçoamento de Pessoal de Nível Superior (CAPES, Brazil, Finance Code 001) and the Fundação de Amparo à Pesquisa do Estado de Minas Gerais (FAPEMIG).

\section{Conflicts of interest}

The authors declare they have no conflicts of interest with regard to the work presented in this report.

\section{Author contributions}

Janaina L Barbosa, Ana-Caroline M DeCastro, and Danilo O Alves conducted the experiment, collected samples, and conducted laboratory analysis. Darcilene M De-Figueiredo designed and supervised the experiment, sample collection, and laboratory analysis as well as the interpretation of statistical results. Janaina L Barbosa, Darcilene M De-Figueiredo, Marcela A Magalhães, Mário H F Mourthé, Marianne Schorer, and Gabriel M Dallago wrote, revised, and edited the manuscript. All authors read and approved the final manuscript.

\section{References}

Almeida JCS, Figueiredo DM, Azevedo KK, Paixão ML, Ribeiro EG, Dallago GM. Intake, digestibility, microbial protein production, and nitrogen balance of lambs fed with sorghum silage partially replaced with dehydrated fruit by-products. Trop Anim Health Prod 2019; 51(3): 619-627. DOI: https://doi.org/10.1007/s11250-018-1734-0

Almeida JCS, Figueiredo DM, Boari CA, Paixão ML, Sena JAB, Barbosa JL, Ortêncio MO, Moreira KF. Performance, body measurements, carcass and cut yields, and meat quality in lambs fed residues from processing agroindustry of fruits. Semina: Ciências Agrárias 2015; 36(1): 541-556. DOI: https://doi.org/10.5433/1679-0359.2015v36n1p541

Alves AM, Fernandes DC, Sousa AGO, Naves RV, Naves MMV. Características físicas e nutricionais de pequis oriundos dos estados de Tocantins, Goiás e Minas Gerais. Brazilian Journal of Food Technology 2014; 17(3): 198-203. DOI: https://doi.org/10.1590/1981-6723.6013

AOAC. Official methods of analysis of AOAC International. 16 ed. ed. Gaithersburg, MD: AOAC International; 1997.

Cardoso AR, Pires CC, Carvalho S, Galvani DB, JochimsF, Hastenpflug M, WommerTP. Intake of nutrients and performance of lambs fed with diets containing different levels of neutral detergent fiber. Ciência Rural 2006; 36(1): 215-221. DOI: https://doi.org/10.1590/S0103-84782006000100033

CEASA-GO. Análise conjuntural 2019. Centrais de Abastecimento de Goiás S/A 2020; [access date: June 10, 2020] URL: https://www. ceasa.go.gov.br/files/ConjuturaAnual/2019/ conjuntura2019 compressed.pdf

Fonseca LD, Vieira TM, Lázaro SF, Silva MLF, Ferreira AVP, Bastos GA, Morais-Costa F, Martins ER, Duarte ER. Eficácia in vitro de extratos aquosos de plantas no controle de nematódeos gastrintestinais de bovinos. Acta Scientiae Veterinariae 2014; 42(1): 1-8.

Frutos P, Hervás G, Ramos G, Giráldez FJ, Mantecón AR. Condensed tannin content of several shrub species from a mountain area in northern Spain, and its relationship to various indicators of nutritive value. Animal Feed Science and Technology 2002; 95(3): 215-226. DOI: https://doi.org/10.1016/S0377-8401(01)00323-6

Geraseev LC, Ribeiro FLA, Bonfá HC, Rufino LMA, Ribeiro Júnior CS, Duarte ER. Ruminal degradationkinetics of diets with pequihullsbran. Ciência Rural 2011; 41(9): 1626-1631. DOI: https://doi.org/10.1590/S0103-84782011000900023 
Guimarães-BeelenPM,Berchielli TT, Buddington R, Beelen R. Efeito dos taninos condensados de forrageiras nativas do semi-árido nordestino sobre o crescimento e atividade celulolítica de Ruminococcus flavefaciens FD1. Arq Bras Med Vet Zootec 2006; 58(5): 910-917. DOI: https://doi.org/10.1590/S0102-09352006000500029

Hall MB, Akinyode A. Cottonseed hulls: working with a novel fiber source. Proceedings of the 11th Annual Florida Ruminant Nutrition Symposium; 2000 Jan 13-14; Gainesville, Florida, USA. Gainesville, Florida, USA: University of Florida.

Homem Junior AC, Silva Sobrinho AG, Yamamoto SM, Pinheiro RSB, Buzzulini C, Lima CSA. Compensatory body weight gain in growing lambs: performance and biometrical measurements. Revista Brasileira de Zootecnia 2007; 36(1): 111-119. DOI: https://doi.org/10.1590/S1516-35982007000100014

Lascano CE, Schmidt A, Barahona Rosales R. Forage quality and the environment. Proceedings of the International Grassland Congress; 2001 São Pedro, São Paulo, Brazil. Piracicaba, São Paulo, Brazil: FEALQ.

Licitra G, Hernandez TM, Van Soest PJ. Standardization of procedures for nitrogen fractionation of ruminant feeds. Animal Feed Science and Technology 1996; 57(4): 347-358. DOI: $\underline{\text { https://doi.org/10.1016/0377-8401(95)00837-3 }}$

Lousada Junior JE, Neiva JNM, Rodriguez NM, Pimentel JCM, Lôbo RNB. Consumo e digestibilidade de subprodutos do processamento de frutas em ovinos. Revista Brasileira de Zootecnia 2005; 34: 659-669. DOI: https://doi.org/http://dx.doi.org/10.1590/ S1516-35982005000200036

Mertens DR. Gravimetric determination of amylase-treated neutral detergent fiber in feeds with refluxing in beakers or crucibles: collaborative study. J AOAC Int 2002; 85(6): 1217-1240.
Nogueira FA, Fonseca LD, da Silva RB, Paiva Ferreira AV, Nery PS, Geraseev LC, Duarte ER. In vitro and in vivo efficacy of aqueous extract of Caryocar brasiliense Camb. to control gastrointestinal nematodes in sheep. Parasitol Res 2012; 111(1): 325-330. DOI: https://doi.org/10.1007/s00436-012-2843-8

NRC. Nutrient requirements of dairy cattle. 7th ed. Washington: The National Academies Press; 2001. DOI: https://doi.org/10.17226/9825

NRC. Nutrient requirements of small ruminants: sheep, goats, cervids, and new world camelids. Washington, DC: The National Academies Press; 2007. DOI: https://doi.org/10.17226/11654

Oliveira ER, Monção FP, Góes RHTB, Gabriel AMA, Paz ICLA, Nääs IA, Santos RC, Moura LV. Bioprodutos do cerrado: Alternativas alimentares na redução da emissão de metano em bovinos - Estudo de caso. Agrarian 2014; 7(24): 369-381.

Patra AK, Saxena J. A new perspective on the use of plant secondary metabolites to inhibit methanogenesis in the rumen. Phytochemistry 2010; 71(11): 1198-1222. DOI: https://doi.org/10.1016/j.phytochem.2010.05.010

Pereira ES, Pimentel PG, Fontenele RM, Medeiros AN, Regadas Filho JGL, Villarroel ABS. Characteristics and yields of carcass and cuts in Santa Ines sheep fed with different concentrations of metabolizable energy. Acta Scientiarum Animal Sciences 2010; 32(4): 431-437.

Ribeiro Junior CS, Rufino LMA, Bonfá HC, Ribeiro FLA, Geraseev LC. Desempenho de caprinos alimentados com diferentes níveis de substituição do capim elefante pelo farelo da casca de pequi. Proceedings of the 49th Reunião Anual da Sociedade Brasileira de Zootecnia; 2009 Jun 14-17; Maringá, Paraná, Brazil. Viçosa, Minas Gerais, Brazil: Sociedade Brasileira de Zootecnia.

Robertson JB, Van Soest PJ. The detergent system of analysis and its application to human foods. In: Sames WPT, Theander O, editors 
The analysis of dietary fiber in food. New York: Marcel Dekker, Inc; 1981. p.123-158

Rosales RB. Condensed tannins in tropical forage legumes: Their characterisation and study of their nutritional impact from the standpoint of structure-activity relationships. Ph.D. Thesis, University of Reading. Reading, Berkshire, United Kingdom, 1999.

Russell JB, O'Connor JD, Fox DG, Van Soest PJ, Sniffen CJ. A net carbohydrate and protein system for evaluating cattle diets: I. Ruminal fermentation. J Anim Sci 1992; 70(11): 3551-3561. DOI: https://doi.org/10.2527/1992.70113551x

Salami SA, Luciano G, O'Grady MN, Biondi L, Newbold CJ, Kerry JP, Priolo A. Sustainability of feeding plant by-products: A review of the implications for ruminant meat production. Animal Feed Science and Technology 2019; 251: 37-55. DOI: https://doi.org/10.1016/j.anifeedsci.2019.02.006

SAS. Statistical Analysis System. Version 9.0. Cary, North Carolina, USA: SAS Institute; 2002.

Sniffen CJ, O'Connor JD, Van Soest PJ, Fox DG, Russell JB. A net carbohydrate and protein system for evaluating cattle diets: II. Carbohydrate and protein availability. J Anim Sci 1992; 70(11): 3562-3577. DOI: https://doi.org/10.2527/1992.70113562x
Soares Júnior MS, Bassinello PZ, Caliari M, Reis RC, Lacerda DBCL, Koakuzu SN. Development and chemical characterization of flour obtained from the external mesocarp of "pequizeiro" fruit. Food Science and Technology 2010; 30(4): 940-948. DOI: https://doi.org/10.1590/S0101-20612010000400017

Trugilho PF, Mori FA, Lima JT, Cardoso DP. Tannin content determination in the bark of Eucalyptus spp. Cerne 2003; 9(2): 246-254.

Valero MV, Farias MS, Zawadzki F, Prado RM, Fugita CA, Rivaroli DC, Ornaghi MG, Prado IN. Feeding propolis or essential oils (cashew and castor) to bulls: performance, digestibility, and blood cell counts. Revista Colombiana de Ciencias Pecuarias 2016; 29(1): 33-42. DOI: https://doi.org/10.17533/udea.rccp.v29n1a04

Van Soest PJ. Nutritional ecology of the ruminant. 2nd ed. Ithaca: Cornell University Press; 1994.

VanSoestPJ,RobertsonJB, LewisBA. Methods for dietary fiber, neutral detergent fiber, and nonstarch polysaccharides in relation to animal nutrition. J Dairy Sci 1991; 74(10): 3583-3597. DOI: https://doi.org/10.3168/jds.S0022-0302(91)78551-2 